\title{
DEMOCRACY IN THE ELECTRONIC GOVERNMENT ERA
}

\author{
Thais Garcia, Claudia Pomar and Hugo Cesar Hoeschl \\ E-Gov, Juridical Intelligence and Systems Institute - IJURIS Florianópólis, Santa Catarina - \\ Brasil
}

Abstract: This article describes Electronic Democracy as an emergent statecraft model. Electronic Democracy is analyzed from a theoretical perspective that proposes edemocracy as the new millennium democratic system. In order to achieve this goal, an e-government concept was required. It is proposed that Electronic Government is presented as the appropriate environment to originate a new role model for managing the public engine: e-democracy. In this particular case, the analyzes focuses on the most important democracy theories - Classic Democracy and Radical Democracy - intending to demonstrate that Electronic Government contains the democracy ideals from both of these theories. Although E-democracy is shown to provide solutions to many social problems, some drawbacks are also discussed. Finally, as a result of this analysis, the ways in which Electronic Government can help the Information Society to become more and more democratic is described.

\section{INTRODUCTION}

The Information Technology and Cybernetic society brings new ways to manage a republic and the institutions that determine the path of society must change appropriately. Due to the social transformations that are occurring, electronic government - or e-gov - is presented as the best option for government administration in the Information Society.

From Brazil to Singapore, countries are developing policies to implement e-gov, which is becoming an ever more present reality in the daily routine of citizens by the day.

E-gov is presented as one of the most important institutions to appear in the new millennium, bringing a new form of thinking with public participa- 
tion in issues which concern them, an emergent and genuine democratic system, contrary to all predictions regarding the future of democracy.

This paper describes an analysis of this new democratic reality that is arising. The target of this study is to demonstrate that electronic democracy - edemocracy - reveals itself as the present and the future of world democracy, a true option for rethinking all democracy theories.

\section{ELECTRONIC GOVERNMENT}

In order to enable a global vision of the new emergent democratic phenomenon, is required a panoramic analysis of the governmental reality that provided the springboard for electronic democracy.

Historically, the fusion of knowledge centred on a relevant and determined objective results in a new concept, which tends to become a referential. In this way, the convergence of information technology with government administration resulted in the birth of e-gov, in order to fulfil the need for the public administration presence in cyberspace, with the intention of reinforcing citizenship and invigorating public administration.

The domination models that characterized the state structures are being standardized with the advent of e-gov, modifying society from the individual level, up to the power bases of worldwide organization. The joining of technology and power, virtual environment and government, brings about a rebirth of concepts, essentially in relation to power and information, which can be assimilated in harmony with the citizenship ideal.

The domination culture is rearranging, as a result of the importance that the virtual environment is earning, as the perfect environment for government - citizen interaction.

This new decentralized and flexible government architecture enables the elaboration of horizontal nets between the actors in society, allowing that egov opposes itself to the centralized and oppressive government. It seems to be the end of the current concept of power. E-gov is born under the sign of democratization.

E-gov is based on complementation - as opposed to a single unit. It appears as a juxtaposition of techniques, processes and structures of governmental management and technology. Juxtaposition because the result is a disconnected fusion that can be divided into two closed subgroups, however, if they return to their original state, there won't be a single common point.

Through this explanation, it is concluded that e-gov - in summary - is the result of an adjusted act: a frenzy of specificities and primary concepts, from which a new attribute is created. E-gov means a reinterpretation of, and also a revolution in, the management of public power, supported by in- 
formation technology, with the intention of supporting the governmental changes.

Zweers \& Planquéii define Electronic Government as an emergent concept that aims to supply or to provide information, services or products, through an electronic environment, starting with public agencies, at any time or place, in order to add value to all stakeholders in the public sphere. [1]

Hoeschl defined the starting objects: "government" is characterized as the public power management with its three powers or spheres (municipal, state and federal), and "electronic" in the sense of digital qualification, or, a digitally qualified government in terms of tools, media and procedures.

In a subsequent work, the author introduces the concept of "Digital Government" and asserts: prepare ourselves to the government forms biggest revolution in History. It is very close, generated by the technology enforce, and it will sprout from the relation between the 'government' and 'connectivity' concepts. [2]

Then, Electronic Government can be defined as the public power management invigorated by the introduction of information technology in its scope, aiming to extend the context of citizenship, due to the possibility of making institutional and internal management faster and more transparent; as it also enables a better integration between society, the government and the marketplace.

\section{A MINIMUM CONCEPT OF DEMOCRACY}

During human history, society has deliberated, incessantly, about government models, as well as has discussed popular participation in public issues and its decision procedures. It is known that many of these discussions are prophecies and exercises to foresee how the government will be conceived in the future. However, there is no doubt that the majority of these forecasts have democracy as a premise. Today, there are few who glimpse the future of humanity far from the democratic ideals. The new theories that appear - especially at universities - are, mostly, rearrangements of past democratic theories or junctions of concepts from diverse theories.

The politic society - meaning a collective life organization - has many ways to determine its organization, according to the place and the time. [3] The proposal of this article is to identify and analyze the new government forms worldwide trend: the electronic democracy.

In this paper, it was opted to discuss some of the most recent and recognized diagnosis of classic democratic theory and also radical democracy, intending to demonstrate that, in both the theories, the electronic democracy can be presented as future trend. 
With didactic purposes, it was opted to detaching aspects of Norberto Bobbio's theory - chosen as defender of classic theory - and John Dewey

- as the precursory of democratic radical modern theory.

\subsection{Bobbio's Classic Democracy Theory}

Bobbio characterizes a minimum concept of democracy by setting a group of rules (primary or basic) that establish who is authorized to make collective decisions and with which are its procedures. [4]

The author quotes minimum requirements to validate democracy, which are: a high number of the members of the group with power attribution to make collective decisions; the rule of majority taking these decisions and, finally, the intrinsic necessity of those who have the power to decide with true possibilities for choosing.

The rights of freedom, opinion and expression are also viewed as estimated presuppositions necessary to a real democratic system. [5]

Bobbio also presents a systematic regarding about the main forms of democracy: direct and representative democracy. In direct democracy, all governmental decisions involve citizens' participation. [6] A representative State, however, is a state in which political deliberations are taken by elected representatives. [7]

In the next topic, we will expose a brief summary of the radical democratic theory view.

\subsection{Dewey's Radical Democracy}

Currently, the main discussion on radical democratic theory is oriented toward the dispute between republicanism and procedimentalism. The reconstruction of the theory of John Dewey presents, nowadays, a third option, in which the author tries to understand democracy as a reflexive means of continuous cooperation. [8]

According to this theory, reducing the idea of democratic formation of the public desires to the numerical principle - the rule of the majority means to understand the society as a disorganized mass of isolated individual purposes which are so incongruous that the intention or the opinion held by the majority must be discovered arithmetically. [9] Hence, Dewey starts to explore the democracy that emerges from society, presented as a social organism in which each individual contributes with its own activity for the reproduction of all.

From this contribution, the concept of complete individual sovereignty emerges, which appears to support the democratic ideal of reciprocal trust. Society being seen as sovereign implies an unlimited development of its per- 
sonality, in which each individual can find its own appropriate function in the society cooperation complex.

For Dewey, the State function, in this context, is to be the political institution that executes this common will through the social cooperation function. This is why the government must be an "alive expression" of the agreed effort to attempt to implement the cooperatively desired wishes.

This concept of State, meaning experimental resolution of problems, is bonded to the cooperative society needs of aiming [10]. To the author, the communicative character of rational resolution of problems can only be achieved where the debate methods of individual certainties assume institutional form, represented by the State.

The State would be a secondary form of association in which the associated public will try to rationally solve unexpected social coordination problems. On the other hand, the State has the duty to assure social conditions under which all citizens can articulate their own interests, without constraints, and with equal chances, which is driven by the law system [11].

According to this point of view, it would be possible for the unlimited opinion formation processes to take on a more important role in real democracy, in order to introduce the concept of "public" as a way to discuss cooperative solutions to society's problems.

This democratic formation of the public statecraft, according to Dewey, would only be possible with the social division of work [12], which would, consequently, allow the creation of a cooperative conscience and responsibility of sharing - in turn making it possible that each individual becomes an active participant in the cooperative society.

\section{THE NEW EMERGENT DEMOCRACY}

Having presented the fundamental base of the most important democratic theories, electronic democracy, known as e-democracy, can now be analyzed, as the most recent perspective on democratic regimes.

Electronic democracy is conceived as emergent political and social reality, resulting from the implementation of electronic government throughout the world. Its fundamental principle is the possibility to extend, significantly, the effective popular participation in government decisions.

It is certain that this new democratic reality brings new perspectives regarding the democratic regimes discussed above.

From the classic democratic theory, e-democracy brings the possibility that e-gov will extend the number of individuals endued with the power of taking decisions for the collective welfare. In this approach, spreading the power to decide on public issues is the main landmark of e-democracy. 
From the radical theory, resurges the self management idea. By the time citizens could, due to the electronic vote, for instance, represent itself in the political decisions, the Internet becomes a mechanism of extinguishing political representation.

Either with a radical perspective or the classic one, it is a fact that e-gov allows the creation of a new relationship between citizen and State, much more interactive than ever, in which the citizen has the real opportunity to acquire a differentiated status in the social organization: the status of active citizen.

Information services - one of the fundamental elements of e-gov- enables the dissemination of information about the government, which contributes to stimulating the critical exercise of the population and also to foment the indirect control of the government actions through the InterNet.

In the Information Society Era, it is known that knowledge is a factor in political and social development. In this Society, knowledge can analogously be compared with what oil meant to the Industrial Revolution, in another words, knowledge is the master mechanism of this new cycle of history.

To publicize the governmental acts - and all other information related to the statecraft - enables the citizen to have a real knowledge of the state machine functioning. Even though that are still researchers who argue that information about public issues always existed, it is the first time in History that society has had such a powerful medium as the Internet. An informed citizen is capable of forming judgments of value and opinions on society matters. Spreading governmental information via e-gov enables much more knowledge generation. And knowledge, nowadays, is power. Spreading knowledge implies spreading the political power, in order to decentralize the power of decision in society.

Although the digital divide is accepted as a barrier to the successful implementation of the e-gov policy, there is also a possibility that the number of conscientious citizens gradually increases. These Citizens can contribute decisively to solving society's problems.

With all the respect, we disagree. It seems that the heart of the quarrel is the fact the critics do not glimpse citizens as protagonist of the electronic government policy, by seeing them as merely participants of the process.

The politics' banalization - pointed by the criticals as one of e-gov problematic aspects - as it will lose part of its typical procedures is an argument constructed under the unconscious will to maintain the status quo.

Banalize is to become banal, common, ordinary. And that's the edemocracy major aim: enable the democratic exercise to become simple to everyone. Perhaps some people can not face it so positively, because to simplify procedures implies the possibility to widen, considerably, the num- 
ber of active participants in the statecraft. The more simple integration between State and society becomes, the more solid will be the democracy.

The electronic democracy does not face the massive population participation as "banalization of politics", but it sees this as an efficient instrument to enhance the exercise of citizenship. The " typical procedures lost" is nothing else than a rethink of the citizenship exercise mechanisms.

The end of bureaucracy does not denote the lost of legislative process' legitimacy, in the opposite, it enables that a huge amount of the population that is in apathyc political situation became active citizens again.

To simplify political participation procedures implies to bring actors who are far distant from the public administration back to the political arena. And if the "politics' banalization" is a consequence of this, it has to be worth.

If the new technologies the responsables for the procedural simplification, it is inevitable to recognize that the solutions employed today - and also the ones being developed - have as focus bringing the citizen back to the political and governamental arena.

There are innumerable e-gov solutions developed especially for the public who is unaware of the technological advances, as, for instance, the Brazilian electronic ballot box.

On this issue, let's discuss the critical of SABBATINI[13]:

The author's concern about the predominance of individualism when taking decisions is extremely pertinent. We agree that the decisions taken, in favor of the common wealth have more legitimacy that the decisions based in particular interests.

However, even if we admitt that a human being is fully capable to separate to its conceptions and its individual yearnings to take decisions aiming exclusively the common wealth, it is not the decision maturation time of the decision that assures the certainty that it was the most adequate choice.

SABBATINI places the emotional factor, said as easily manipulable, as factor of risk to the politicals decisions, almost considered as an unadvised decision. It is evident that imagine that the information cannot be manipulated is a naivety, but to face this as undoubtful truth implies to recognize that we are all government or media marionettes.

Taking decisions politics, in this proposal, is a way to adapt the popular participation procedures to the speedness of nowadays social transformations.

If the biggest difficulty of the Brazilian Legislative is to keep the legislation updated -in accord with the social transformations -, the electronic democracy enables that this legislation can be modified more easily, in order to follow the changes that are to occurring in a short period of time.

Let imagine, for example, if to each significant change of the legislation a popular countersignature was made. This democratic institute, presented in 
Brazilian's Federal Constitution of 1988, in article 14, II, is the simplest alternative available to consult the popular in the present time.

And even if the simplest alternative of popular consultation demands a huge mobilization from the public administration and from the civil society, why can't we create simpler alternatives?

With electronic government, the popular consultation can have its concept extended. And it is not possible to see the rapidity and the agility of this process as a negative factor, because these are its greatest attractives. The Internet revolution gives the possibility of a governmental performance finally updated to the social trends by the time they occur.

As the number of well-enable electronic citizens increases, the greater will be the legitimacy of the consultation or the vote. However, the illusion of that the universal suffrage by itself would guarantee the freedom of the people was already fought by innumerable philosophers, detaching BAKUNIN. [14]

This quarrel retraces to the ideals of Dewey, ideals of sovereign cooperative society, in which - as it was said in the 4.2.2 chapter - the State is an instrument through which the individuals cooperates between itself with the purpose to solve the society problems.

Dewey considered that the social division of the work stimulated the social conscience in the individuals, indispensable the successful functioning of the cooperative society. However, we consider a small change in its theory: the electronic government will be capable to create the political and social conscience so desired by the radical democrats, either by means of disseminating the knowledge, either for magnifying the social participation in the political decisions.

As we can see, electronic government is retaking lots of the democratic ideals forgotten ahead the impossibility of applying them in the practical.

Electronic democracy is only starting its first steps. Digital inclusion programs and the reduction of electronic equipment prices are indispensable for its existence. However, we can not deny this democratic reality while there are still people without access to the Internet.

We have to keep in mind that electronic government is also an environment where the community can its problems and solution. Who knows, maybe from the proper electronic government, does not appear excellent a proposal of inclusion, as a result of the citizen's interaction with government, research groups, organizations and many others State actors? 


\section{FINAL CONSIDERATIONS}

Even the arduous critical of the electronic democracy do not resist to a strong analysis. Perhaps due to the some researchers exaggerated pessimism, that say that is impossible to accept electronic democracy nowadays.

Pessimism this that is, in our opinion, fear of the stranger, a fear that devastates the humanity since its begging. As well as the wheel scared the prehistoric ones and the healers had been burned in the Average Age, defending electronic democracy is not an easy job.

Lots of issues can be argued in the theorical and ideological sphere, but, the electronic democracy is already part of our daily reality, even if we didn't have faced it yet.

Too precious time is lost by arguing on the e-democracy's plausibility, when the fact is that electronic government in makes us gain time and efficiency while citizens. The electronic democracy is simply a direct reflex of what occurs in the political and social sphere. It is impossible to conceive the Information Society - fulled of knowledgement and for cybernetics that can not accept that a new model of democratic system had appeared, "electronically".

The democracy based on bureaucracy and extreme organiscism is inapt to answer to the current society yearnings. If all the segments of human life - either science or the intersubjective relations - are is a constant process of transformation, why can't we think that the governmental model does not require any modernization?

Electronic democracy allows the development of many kinds of technological solutions that aim to approach the citizen of the state apparatus and its political decisions.

In the electronic democracy era, technology will finally have the possibility to "redeem" itself from the society. Technological solutions can be responsible, for example, to promote the digital inclusion.

There are innumerable ways in which this new form of democracy can be exerted and managed. We, as citizens of the future, have the power to became part of this process, and to start searching for the best alternatives of exerting the democratical ideal in this new political and governmental arena.

\section{REFERENCES}

1. Zweers K \& Planqué K. Electronic Government. From a Organizational Based Perspective Towards a Client Oriented Approach", In: Designing E-Government, Prins J.E.J. (ed.), Kluwer Law International: 2001, pp. 92 
2. HOESCHL, H. C. Quarto instância: Os principais aspectos do Governo Eletrônico. Consultor Jurídico Magazine, October, 7th, 2002.

3. BOBBIO, Norberto. . A teoria das formas de governo. Trad. de Sérgio Bath, $4^{\mathrm{a}}$ ed. Brasília: Editora Universidade de Brasília, 1985, p. 31.

4. BOBBIO, Norberto. O futuro da democracia: uma defesa das regras do jogo. Trad. de Marco Aurélio Nogueira. Rio de Janeiro: Paz e Terra, 1986, p. 18.

5. . Op. cit., p. 19-20.

$6 . \quad$ Op. cit., p.42.

$7 . \quad$ Op. cit., p. 44.

8. HONNETH, Axel in Democracia hoje: novos desafios para a teoria democrática contemporânea. Jesse de Souza (org). Brasília: Editora Universidade de Brasília, 2001, p. 65 .

9. . Op. cit., p. 66-67.

10.DEWEY, John. Ethics of Democracy in The Early Works of John Dewey, 1882-1898, vol. 1, ed. Jo Ann Boydston, Carbondale: Southern Illinois Universtity Press, 1969, pp. $227-$ 249.

11. . Op. cit, p. 71.

12.DEWEY apud HONNETH, op. cit., p. 72.

13.SABBATINI, Renato M. E. Democracia Eletrônica. Campinas: Jornal Correio Popular, 30/7/92. Disponível em http://www.nib.unicamp.br/sabbatin.htm. Acesso em 19 de novembro de 2002.

14.BAKUNIN, Mikahil. A ilusão do sufrágio universal. Avaible in http://www.phoenixlibrary.org. Access in February, 15th, 2003. 